\title{
China's Suspended Death Sentence with a Two-Year Reprieve: Humanitarian Reprieve or Cruel, Inhuman and Degrading Punishment?
}

\author{
Matthew Seet ${ }^{1}$
}

\section{INTRODUCTION}

An especially fascinating feature of China's domestic criminal law is the suspended death sentence, the sihuan zhidu, where a two-year reprieve may be pronounced simultaneously with an imposition of the death sentence if immediate execution is not deemed "necessary." At the end of the twoyear reprieve, the death sentence may be commuted to life imprisonment if the convict has not committed an "intentional crime" during the two-year reprieve, or to a fixed-term imprisonment of 25 years if the convict has performed "great meritorious service." 3 This idea of a death sentence with a stay of execution was briefly mentioned by Sir Thomas More in his work,

1 Sheridan Fellow, Faculty of Law, National University of Singapore. The author would like to thank Michelle Miao, Margaret Lewis, and Marcellene Hearn for the helpful discussions which have contributed to this Article. All views expressed and all errors in this Article are entirely the author's own.

2 Zhonghua Renmin Gongheguo Xing Fa (1997 Xiuding) (中华人民共和国刑 法 (1997修订)) [Criminal Law of the People's Republic of China (97 Revision)] (promulgated by the Standing Comm. Nat'l People's Cong., July 1, 1979, amended Mar. 14, 1997, effective Dec. 25, 1999), art. 50, CLI.1.17010(EN) (Lawinfochina) [hereinafter 1997 Criminal Law].

3 Zhonghua Renmin Gongheguo Xing Fa Xiuzhengan (Ba) (中华人民共和国刑法 修正案(八)) [Eighth Amendment to the Criminal Law of the People's Republic of China] (promulgated by the Standing Comm. Nat'l People's Cong., Feb. 25, 2011, 
Utopia, ${ }^{4}$ in the sixteenth century, but was never developed into a concept, much less a reality. ${ }^{5}$

Chinese officials consider the suspended death sentence an "original creation" of China, and scholars consider it a "uniquely Chinese contribution to the global panoply of penalties." 7 This legal innovation which is unique to China must be differentiated from the pardon or clemency procedures of other states which have retained the use of capital punishment (in practice or only in their law books $)^{8}$ as required under international human rights

effective May 1, 2011), art. 4, CLI.1.145719(EN) (Lawinfochina) [hereinafter 2011 Amendment VIII].

4 Thomas Moore, Utopia 41 (R. Robinson trans., Wordsworth Editions Ltd. 1997) ("But when the sentence of death is given, if then the king should command execution to be deferred and spared, and would prove this order and fashion, taking away the privileges of all centuries, if then the proof should declare the thing to be good and profitable, then it were well done that it were established; else the condemned and reprieved persons may as well and as justly be put to death after this proof, as when they were first cast. Neither any jeopardy can in the mean space grow hereof.").

5 Zhao Zuojun, The Suspension-of-Execution System and Limiting the Application of the Death Sentence, 36 Contemporary Chinese Thought 53, 74 n.1 (2005).

6 Info. Office of the State Council of the China, Guarantee of Human Rights In China's Judicial Work, in Human Rights in China, White Papers Gov't, (Nov. 1991), http://www.china.org.cn/e-white/7/7-IV.htm.

7 Michael Palmer, The People's Republic of China, in 2 Capital Punishment: Global Issues and Prospects 105, 120 (Peter Hodgkinson \& Andrew Rutherford eds., 1996).

8 These terms are used interchangeably to refer to the substitution of the death sentence with a lesser penalty than death. Roger Hood \& CArolyn Hoyle, The Death Penalty: A Worldwide Perspective 258 (4th ed. 2008). China does not have an effective clemency procedure, or any other form of pardon or amnesty apart from the suspended death sentence. Id. The Chinese Constitution confers power on the President to order special pardons (Article 80) and this must be approved by the Standing Committee of the National People's Congress. XIAnfa art. 80 (1982) (China). However, this is a dead letter as no Chinese prisoner has been pardoned since 1975. According to the National People's Congress Standing Committee, special pardons have been granted on the following occasions: September 17, 1959; November 19, 1960; December 16, 1961; March 30, 1963; December 12, 1964; March 29, 1966 and March 17, 1975. Nicola MacBean, The 
standards. ${ }^{9}$ Unlike in pardon and clemency procedures in other retentionist states, the commutation of the suspended death sentence to life or fixed-term imprisonment is initiated by the criminal justice system itself and the convict does not have the right to apply for such commutation. ${ }^{10}$ The suspended death sentence has developed into one of the most important kinds of penalties used by Chinese courts particularly in the $1980 \mathrm{~s},{ }^{11}$ but until recently, little has been written about the suspended death sentence. ${ }^{12}$ It perhaps only gained worldwide attention in 2012 when Gu Kailai, the wife of Politburo member Bo Xilai, was convicted of murdering Neil Heywood and was sentenced to death with a two-year reprieve but was not executed. ${ }^{13}$

While the suspended death sentence has been praised for being "humane" and respecting the right to life by reducing the total number of executions in China (which currently conducts the largest number of executions in the world today), ${ }^{14}$ it has also been criticised for being "cruel" and "inhuman," given that the convict may remain uncertain and anxious as to his fate at the end of the two-year reprieve. Thus, this Article aims to address the question of whether the suspended death sentence violates the prohibition against cruel, inhuman, and degrading punishment in

Death Penalty in China: A Baseline Document 29 n.47 (The Rights Practice, 2003), http://www.ecba.org/extdocserv/DP_Baseline.pdf.

9 International Covenant on Civil and Political Rights art. 6(4), Dec. 16, 1966, S. Treaty Doc. No. 95-20, 999 U.N.T.S. 171 [hereinafter ICCPR] states "[a]nyone sentenced to death shall have the right to seek pardon, or commutation of sentence. Amnesty, pardon or commutation of the sentence of death may be granted in all cases of capital punishment."

10 MacBean, supra note 8.

11 Palmer, supra note 7.

12 Zhang Ning, The Debate Over the Death Penalty in Today's China, 62 ChinA Perspectives 1, 6 (2005) (many studies done on this subject are of theoretical character and what is lacking is precise data).

13 See Tania Branigan, Gu Kailai Given Suspended Death Sentence Over "Despicable" Murder, Guardian (Aug. 20, 2012), http://www.theguardian.com/world/2012/ aug/20/gu-kailai-suspended-death-sentence.

14 Death Sentences and Executions 2014, Amnesty InT'L (Mar. 31, 2015), http://www. amnestyusa.org/research/reports/death-sentences-and-executions-2014 (“[C]hina again carried out more executions than the rest of the world put together.”). 
international law. After providing the background of the suspended death sentence and discussing the criticisms of it according to human rights standards (Part 2), this Article then examines international, regional and domestic jurisprudence on the "death row phenomenon" and argues that the suspended death sentence does not amount to cruel, inhuman and degrading punishment under international human rights law (Part 3). Finally, this Article concludes by by exploring the potential implications of this issue for other States, especially those which have ratified the International Covenant on Civil and Political Rights (ICCPR) (Part 4).

\section{THE SUSPENDED DEATH SENTENCE AND INTERNATIONAL HUMAN RIGHTS LAW}

\section{a. The 1979 Criminal Law and 1997 Criminal Law (as amended in 2011 and 2015)}

Although the suspended death sentence has had a long history in China, ${ }^{15}$ it was only in 1979 that China's criminal law included the suspended death

15 David Johnson \& Franklin Zimring, The Next Frontier: National Development, Political Change, and the Death Penalty in Asia 256 n.33 (2009) ("death sentence with a two-year reprieve has many precursors in Chinese history, but the modern version was created by Mao."). Prior to the Mao era, some scholars claim that the earliest form of the suspended death sentence may be traced to the Han Dynasty, where death row inmates were given the opportunity for meritorious service and sufficient reform during the two-year suspension, so that their lives would be spared. Hong Lu \& Terence D. Miethe, China's Death Penalty: History, Law and Contemporary Practices 66 (2007). Others note how, in the Ming and Qing Dynasties, the Emperor issued the suspended death sentence in some cases which were subsequently reviewed two years later by the special high court in autumn. Derk Bodde \& ClarenCE Morris, LAW IN IMPERIAL China: Exemplified By 190 Ch'ing Dynasty Cases, With Historical, SoCIAL, AND JURIDICAL COMMENTARIES 138 (1967); Zhang Ning, supra note 12, at 11. At the height of the first Movement to Suppress Counterrevolutionaries in May 1951, according to Mao, the counter-revolutionaries who should be subject to immediate execution were those who incurred "blood debts" or committed extremely serious harm to the national interest, while those who "may be saved" through the death sentence with a two-year reprieve who those whose harm on the national interest had not "reached an extreme" or where the masses were not direct 
sentence. ${ }^{16}$ After stating that only criminals who have committed the most "heinous crimes" were to be sentenced to death, the 1979 Criminal Law provided that a two-year reprieve was to be pronounced simultaneously with the death sentence if immediate execution was "not deemed necessary," and the criminal was to undergo reform through labour during the two-year reprieve. ${ }^{17}$ There were three possible outcomes at the end of the two-year reprieve. One, if the convict had shown "true repentance" during the reprieve, the death sentence was to be commuted to life imprisonment. ${ }^{18}$ Two, if the convict had not only shown "true repentance" but had also performed "meritorious service," the death sentence was to be reduced to a fixed-term imprisonment of 15 to 20 years. ${ }^{19}$ Three, if the convict had "resisted reform in a flagrant manner," the convict was to be "executed by means of shooting," 20 subject to the approval of the Supreme People's Court. ${ }^{21}$ Resisting reform in itself did not necessarily lead to execution;

victims. Mao Tsetung, Strike Surely, Accurately and Relentlessly in Suppressing Counter-Revolutionaries, in 5 Selected Works of Mao TseTung 53, 54-55 (1977). Sparing their lives would prevent the masses (who were not direct victims) from being confused as to the execution, maintain a "large pool of labor power" and avoid potential wrongful executions. Id. According to Mao, 10-20 percent should be executed immediately, while the remaining $80-90$ percent should be saved through the reprieve. $I d$.

16 Hong Lu \& Terence D. Miethe, supra note 15, at 66.

17 Zhonghua Renmin Gongheguo Xing Fa (中华人民共和国刑法) [Criminal Law of the People's Republic of China] (promulgated by the Standing Comm. Nat'l People's Cong., July 1, 1979, effective Jan. 1, 1980), art. 44, CLI.1.556(EN) (Lawinfochina) (although the death penalty shall not be imposed on persons who had not reached the age of 18 at the time the crime was committed, persons above the age of 16 but below the age of 18 may be sentenced to death with a two-year suspension if the crime committed was particularly serious).

$18 \quad$ Id. art. 46.

19 Id.

20 Id. art. 45.

21 Id. art. 46. According to MacBean, this emphasis on the re-education and reform of offenders reflects the historical and political "heritage" of the suspended death sentence as having been used extensively against political opponents. MacBean, supra note 8 , at 23 . 
the convict had to have "refuse[d] in a particularly serious manner to mend [his or her] ways." 22

As per the 1997 Criminal Law which has replaced the 1979 Criminal Law, the death penalty shall apply only to criminals who have committed "extremely serious" crimes; a two-year stay of execution may be pronounced simultaneously with the imposition of the death sentence if immediate execution is not deemed necessary. ${ }^{23}$ Technically, the suspended death sentence is not an "alternative" sentence in a category separate from immediate execution; rather, it is another way of implementing the death penalty, ${ }^{24}$ with the two-year reprieve as an "appendage." ${ }^{25}$ The 1997 Criminal Law is silent on exactly when a crime is to be deemed "serious" and is "extremely" so, and also on exactly when immediate execution is to be deemed to be "necessary." ${ }^{6}$ The convict may be executed during or at the end of the two-year reprieve if he or she committed an "intentional crime" under "heinous circumstances" during the two-year reprieve, subject to the Supreme People's Court's approval. ${ }^{27}$ If he or she committed an "intentional

22 A National People's Congress Legal Affairs Commission official, Sha Qianli, stated after the adoption of the 1979 Criminal Law that "[g]enerally speaking, those receiving the reprieve will not be executed as long as they do not refuse in a particularly serious manner to mend their ways." AmNesty Int'L, China: Violations of Human Rights: Prisoners of Conscience and the Death Penalty in the People's Republic of China 63 (1984). For example, Jiang Qing and Zhang Chunqiao, two former members of the Gang of Four, had their sentences commuted at the end of the two-year reprieve because the Supreme People's Court found that "the two criminals had not resisted reform in a flagrant way." Id. at 64 .

231997 Criminal Law, supra note 2, art. 48.

24 MacBean, supra note 8, at 22.

25 Zhao Zuojun, supra note 5, at 75. However, in practice, judges have regarded the suspended death sentence as an "independent category of punishment" or another "level of custodial punishment." Susan Trevaskes, The Death Penalty in Contemporary China 120 (2012).

26 Susan Trevaskes, China's Death Penalty: The Supreme People's Court, the Suspended Death Sentence and the Politics of Penal Reform, 53 British Journal of Criminology 482, 488 (2013).

27 Zhonghua Renmin Gongheguo Xing Fa Xiuzhengan (Jiu) (中华人民共和国刑法 修正案(九)) [Ninth Amendment to the Criminal Law of the People's Republic of 
crime" not under such "heinous circumstances," the start date of his or her two-year reprieve is reset. ${ }^{28}$ There are three possible outcomes at the end of the two-year reprieve for the convict who did not commit an "intentional crime." One, the death sentence is commuted to life imprisonment ${ }^{29}$ which may be further commuted to a fixed-term imprisonment of at least 25 years. ${ }^{30}$ Two, if the convict performed "great meritorious service,"31 the convict's death sentence may be commuted to a fixed-term imprisonment of 25 years $^{32}$ which may be further commuted to a term of at least 20 years, ${ }^{33}$ with the courts retaining the power to modify the length of fixed-term imprisonment based on the circumstances of the crime, for "recidivists" or persons who have committed the following crimes: "intentional homicide, rape, robbery, kidnap[ping], arson, explosion, throw[ing] dangerous substance[s] or organized violent crime." 34 Three, if a convict was given the suspended death sentence after having been found guilty of corruption, specifically for embezzling an "especially large" amount of money, at the end of the two-year reprieve, his

China] (promulgated by the Standing Comm. Nat'l People's Cong., Aug. 29, 2015, effective Nov. 1, 2015), art. 2, CLI.1.145719(EN) (Lawinfochina) [hereinafter 2015 Amendment VIIII].

28 Id.

291997 Criminal Law, supra note 2, art. 50.

302011 Amendment VIII, supra note 3, art. 15(3)

31 1997 Criminal Law, supra note 2, art. 50. Article 78 defines "meritorious service" as including the following: "preventing another person from conducting major criminal activities;" "informing against major criminal activities conducted inside or outside prison and verified through investigation;" "having inventions or important technical innovations to one's credit;" "coming to the rescue of another in everyday life and production at the risk of losing one's own life;" "performing remarkable services in fighting against natural disasters or curbing major accidents;" and "making other major contributions to the country and society." Id. art. 78.

322011 Amendment VIII, supra note 3, art. 4.

33 Id. art. 15(3).

34 Id. art. 4. 
or her suspended death sentence may be commuted to life imprisonment without the possibility of parole or commutation. ${ }^{35}$

\section{b. Critique of the Suspended Death Sentence with Regard to International Human Rights Law}

The suspended death sentence has been praised for protecting human lives, ${ }^{36}$ because its use has effectively reduced executions in China, ${ }^{37}$ while it still remains an attractive "substitute sanction that carries something close to the symbolic weight of a death sentence." 38 A human rights nongovernmental organisation has even encouraged China to increase its use of the suspended death sentence for this very reason. ${ }^{39}$ However, the suspended death sentence has also been criticised for violating other human rights. First, China's application of the suspended death sentence may run "counter to the principle of the presumption of innocence" ${ }^{40}$ which is well-

352015 Amendment VIIII, supra note 27, art. 44.

36 Trevaskes, supra note 25, at 16.

37 According to a mid-2000s study, there was an approximately $50 \%$ decline in the number of executions in the mid-2000s from the mid-1990s, which was brought about by the suspended death sentence in two ways. Hong Lu \& Terence D. Miethe, supra note 15, at 75. First, it was extremely rare for the Procuratorate (the Chinese-equivalent of a Western legal system's state prosecutor) to protest a ruling of suspended death sentence to the high court for a heavier sentence, which is immediate execution. Id. Second, Chinese courts increasingly preferred to use the suspended death sentence. Id. Eventually, in October 2006, the Organic Law of the People's Court was amended to return to the SPC its exclusive authority to review and approve all death sentences from 1 January 2007. Trevaskes, supra note 26 , at 486 . In 2007 , the SPC announced that the annual number of suspended death sentences exceeded the number of death sentences with immediate execution and the number of executions in China in 2007 had decreased by a massive 33\%. Id.

38 Franklin Zimring \& David Johnson, Public Opinion and Death Penalty Reform in the People's Republic of China, 3 City University of Hong Kong Law Review 189, 195 (2012) (where the authors term the suspended death sentence a "natural consolation prize" for prosecutors and victims' families).

39 Promoting Increased Transparency in China's Criminal Justice System, Dui HuA g 11 (Feb. 2009), http://duihua.org/wp/?page_id=2536.

40 Johnson \& Zimring, supra note 15, at 283 n.67. 
established in international law. ${ }^{41}$ The suspended death sentence has often been employed by Chinese courts as an alternative to immediate execution in order to serve as a compromise between judges' differing opinions, and to "leave some leeway" in cases where the evidence is incomplete such that the court has doubts as to whether the accused is guilty. ${ }^{42}$ Rather than act on the basis of "if in doubt, declare not guilty" as the presumption of innocence requires, judges often act on the basis of "if in doubt, reduce the sentence" ${ }^{43}$.

Second, China's application of the suspended death sentence raises issues of equality before the law, which is provided for under international human rights law. ${ }^{44}$ Suspended death sentences are "increasingly associated with selective enforcement along socio-economic and political-power

41 The right to the presumption of innocence is well established in international law. Article 11(1) of the Universal Declaration of Human Rights states, "Everyone charged with a penal offence has the right to be presumed innocent until proved guilty according to law." G.A. Res. 217 (III) A, Universal Declaration of Human Rights, art. 11 (Dec. 10, 1948) [hereinafter UDHR]. Similarly, Article 14(2) of the ICCPR states, "Everyone charged with a criminal offence shall have the right to be presumed innocent until proved guilty according to law." ICCPR, supra note 9, art. 14(2). Specifically with regard to the standard of proof in death penalty cases, the United Nations Safeguards Guaranteeing Protection of the Rights of Those Facing the Death Penalty states, "Capital punishment may be imposed only when the guilt of the person charged is based upon clear and convincing evidence leaving no room for an alternative explanation of the facts." Economic and Social Council Res. 1996/15, art. 4 (July 23, 1996).

42 Trevaskes, supra note 25, at 109, 129.

$43 \quad I d$. at 112.

44 Both the UDHR and ICCPR state, "All are equal before the law and are entitled without any discrimination to equal protection of the law." UDHR, supra note 41, art. 7; ICCPR, supra note 9, art. 26. 
lines, ${ }^{35}$ and more frequently used in cases of corruption, ${ }^{46}$ economic crimes, ${ }^{47}$ and when monetary compensation has been paid to victims' families. ${ }^{48}$ The suspended death sentence is thus increasingly perceived as a "get-out-of-death card available to wealthy and powerful defendants" while "regular death sentences" where the convict is immediately executed "tend to be disproportionately imposed on those with little education and social standing." 50

The third criticism of the suspended death sentence, which this article shall focus on, is that it constitutes cruel, inhuman and degrading punishment under international law. According to critics, the suspended death sentence is "inhuman" because the convict who faces one of two outcomes at the end of the two-year reprieve - imprisonment or execution ${ }^{51}$ - is placed on "tenterhooks" and is forced to undergo the "enormous psychological burden" ${ }^{52}$ of being in a state of anxiety and suspense for such a long time as

45 Margaret Lewis, Leniency and Severity in China's Death Penalty Debate, 24 Columbia Journal of Asian Law 303, 325 (2011). A Chinese writer in a Hong Kong-based, pro-PRC journal criticised Chinese authorities for their inability to reconcile their commitment to the principle of "equality before the law" with their conduct of routinely executing embezzlers and rapists while sparing the life of Jiang Qing who persecuted thousands of people and caused the death of many during the Cultural Revolution." Shaochuan Leng \& Hongda Chiu, Criminal Justice In Post-Mao China: Analysis and Documents 106 (1985).

46 Lewis, supra note 45, at 307.

47 Katie Lee, China and the International Covenant on Civil and Political Rights: Prospects and Challenges, 6 Chinese Journal of International Law 445, 464 (2007) (the suspended death sentence is "a legitimate safety valve the courts can use for economic crimes, such as tax evasion, which attract the death penalty as the ultimate sanction.").

48 Lewis, supra note 45, at 309 n.24.

49 Id. at 325-26 (further noting how these sentiments are expressed in Chinese phrases like "tan guan mian si (corrupt officials are exempted from death)" and "mian si pai (death exemption card).”).

50 Meaghan Sunderland, Criminal Law Reform in the People's Republic of China: Any Hope for those facing the Death Penalty?, 8 Appeal: Review of Current LAW AND LAW ReForm 18, 27 (2002).

51 Zhao Zuojun, supra note 5, at 75 n.15.

$52 \quad I d$. at 58. 
to whether he or she will eventually face execution. ${ }^{53}$ When China described the suspended death sentence while presenting its initial report to the United Nations Committee Against Torture in 1990, a committee member found the suspended death sentence "particularly cruel" 54 and another committee member agreed, stating that the suspended death sentence "amounted to inhuman and degrading treatment." ${ }^{55}$ Chinese officials have historically been sensitive to such criticism, extolling the suspended death sentence to be of the "greatest humaneness" and embodying the spirit of "revolutionary humanism." ${ }^{56}$ This controversy of whether the suspended death sentence is "humane" or whether it amounts to "cruel, inhuman and degrading punishment" shall now be explored. ${ }^{57}$

\section{THE SUSPENDED DEATH SENTENCE AND THE PROHIBITION OF CRUEL, INHUMAN AND DEGRADING PUNISHMENT}

In order to address the question of whether the suspended death sentence constitutes cruel, inhuman and degrading punishment, it is crucial to examine the jurisprudence of international and domestic courts regarding the "death row phenomenon." 58 The "death row phenomenon" was defined

53 See Zhang Ning, supra note 12, at 5 ("[T]his sentence can scarcely be regarded as humane, since it puts the condemned in a state of anxiety for the two years of their reprieve.").

54 U.N. Comm. Against Torture, Initial Report of China, 37, U.N. Doc. CAT/C/ SR.51 (May 4, 1990).

55 Id. 94.

56 The Chinese have maintained that the spirit of "revolutionary humanism" in the Chinese criminal law is embidied in the suspended death sentence. Jerome CoHEN, The Criminal Process in the People’s Republic of China, 1949-1963 537 (1968). The Minister of Public Security, Lo Jui-ch'ing, stated in 1959: “Imperialists have denounced [the suspended death sentence] as the greatest cruelty. We say that this is the greatest humaneness. The criminals themselves understand this. Sentencing them to death and suspending execution of their sentence gives to these persons, allowed to live on under the sword of the people's government, a last opportunity to reform .... Where was there ever in ancient or modern times, in China or abroad, so great an innovation? Where could one find in the capitalist world so humane a law?" Id. at 539.

57 Zhao Zuojun, supra note 5, at 75 n.15.

58 Soering v. United Kingdom, App. No. 14038/88, 161 Eur. Ct. H.R. (ser. A) (1989). 
in the landmark European Court of Human Rights (ECtHR) case of Soering v. United Kingdom ${ }^{59}$ as the "combination of circumstances to which [a prisoner] would be exposed if . . . he [or she] were sentenced to death,"60 "with the ever present and mounting anguish of awaiting execution of the death penalty." ${ }^{\prime 1}$ In that case, the ECtHR held that extradition of an individual from the United Kingdom to the United States to face charges for a first-degree murder charge, without assurances from the United States government that the death penalty would not be carried out, violates the prohibition against "torture ... and inhuman and degrading treatment or punishment" in Article 3 of the European Convention of Human Rights (ECHR). ${ }^{62}$ It was not the death penalty itself which the ECtHR found to be offensive to Article 3 of the ECHR, ${ }^{63}$ but the death row phenomenon. ${ }^{64}$

$59 \quad I d$.

$60 \quad$ Id. g 81.

61 Id. 111.

62 Id. European Convention on Human Rights, art. 3, Nov. 4, 1950, 213 U.N.T.S. 221, 224 [hereinafter ECHR] states, "No one shall be subjected to torture or to inhuman or degrading treatment or punishment."

63 The majority concluded that recognition of the death penalty in article 2(1) of the Convention as a limitation on the right to life ruled out such a dynamic interpretation. Soering App. No. 14038/88, 161 Eur. Ct. H.R. (ser. A) gg 102-103. Furthermore, the majority considered that the adoption of an optional protocol to the Convention abolishing the death penalty in time of peace was further evidence that the Convention itself should not be given an abolitionist mission. Id.

$64 \quad I d .9111$. 
Soering is thus an especially important decision which "broke new ground, providing a basis for other courts to embrace the death row phenomenon." ${ }^{\prime 6}$

The death row phenomenon (which should be differentiated from the death row syndrome ${ }^{66}$ ) is a relatively new legal doctrine used by abolitionists as an "alternative"67 and "collateral"68 attack on the death penalty in the judicial forum. In such instances, it is not the death sentence which is directly challenged ${ }^{69}$ (which would be problematic at both international and domestic levels, given the international human rights instruments'

65 Patrick Hudson, Does the Death Row Phenomenon Violate a Prisoner's Human Rights Under International Law, 11 European Journal of InTERnational LaW 833, 842-43 (2000). On the significance of the Soering decision, see Richard Lillich, Note and Comment, The Soering Case, 85 American Journal of International LaW 128, 128-49 (1991); Susan Marks, Yes, Virginia, Extradition May Breach the European Convention on Human Rights, 49 Cambridge Law Journal 194, 194-97 (1990); Christine van den Wyngaert, Applying the European Convention on Human Rights to Extradition: Opening Pandora's Box?, 39 International and Comparative Law Quarterly 757, 757-79 (1990).

66 David Sadoff, International Law and the Mortal Precipice: A Legal Policy Critique of the Death Row Phenomenon, 17 Tulane Journal of International and Comparative LaW 77, 84-85 (2008) ("The death row phenomenon must not be conflated with the similarly sounding term, 'death row syndrome'. Both terms denote a degree of mental trauma in connection with the death row experience and both potentially can justify reprieve from execution, but their commonality essentially ends there. The phenomenon relates to the circumstances on death row, including the duration and isolation of detention, as well as the uncertainty as to the time of execution that can be tantamount to a form of psychological maltreatment, while the syndrome pertains strictly to the mental effects themselves that derive from prolonged death row detention, such as incapacitated judgment, mental illness, or suicidal tendencies. It follows that the phenomenon, unlike the syndrome, does not per se require demonstrable proof of mental suffering. In addition, the two concepts are implicated in distinct contexts: while the phenomenon alone can arise under an extradition scenario, only the syndrome is germane when mental competency claims are raised.").

67 Kealeboga Bojosi, The Death Row Phenomenon and the Prohibition Against Torture and Cruel, Inhuman or Degrading Treatment, 4 African Human Rights LAW Journal 303, 305 (2004).

68 Hudson, supra note 65, at 833.

$69 \quad I d$. 
and domestic constitutions' explicit recognition of the death penalty as an exception to the right to life ${ }^{70}$ ). Rather, what is challenged is the "yearslong wait for the scaffold under gruesome conditions, both physical and psychological." ${ }^{71}$ Given that China's suspended death sentence with a twoyear reprieve also involves a delay of the execution for a period of time, an examination of international and domestic jurisprudence on the death row phenomenon is necessary to address the question of whether the suspended death sentence constitutes cruel, inhuman and degrading treatment.

In such an examination of the death row phenomenon jurisprudence, it is important to recognize that different international and domestic courts use different conventions and constitutions as the source of law, which, in turn, employ different terminology: the International Covenant on Civil and Political Rights prohibits "cruel, inhuman or degrading treatment or punishment"72 and the ECHR prohibits "inhuman or degrading treatment or punishment." ${ }^{\prime 3}$ While the terminologies are different, the underlying concept is similar, given that each provision was "adopted to protect persons from unnecessary and undue suffering." 74 Hence, the phrase "cruel, inhuman and degrading punishment" will be used throughout this article for purposes of uniformity.

\section{a. Is There a Real Risk of the Death Sentence being Carried Out?}

According to the death row phenomenon jurisprudence, in order for any detention on death row with delayed execution to constitute cruel, inhuman and degrading punishment, the threshold requirement of a "genuine risk

70 See ICCPR, supra note 9, art. 6(2); ECHR, supra note 62, art. 2(1); American Convention on Human Rights, art. 4, Nov. 21, 1969, 1144 U.N.T.S. 143; cf. African Charter on Human and Peoples' Rights, June 27, 1981, 21 I.L.M. 58 which is silent on the issue of the death penalty. Further, Constitution of Jamaica Aug. 6, 1962, art. 14(1) provides, "[n]o person shall intentionally be deprived of his life save in execution of the sentence of a court in respect of a criminal offence of which he has been convicted."

71 William Schabas, International Law and Abolition of the Death Penalty, 55 Washington ANd LeE LAW Review 797, 809 (1998).

72 ICCPR, supra note 9, art. 7.

73 ECHR, supra note 61, art. 3.

74 Hudson,supra note 65, at 837. 
that the death penalty will be implemented"75 must be met. The ECtHR in Soering maintained that:

[T] he inquiry must concentrate firstly on whether Mr. Soering runs a real risk of being sentenced to death in Virginia, since the source of the alleged inhuman and degrading treatment or punishment, namely the 'death row phenomenon', lies in the imposition of the death penalty. Only in the event of an affirmative answer to this question need the court examine whether exposure to the 'death row phenomenon' in the circumstances of the applicant's case would involve treatment or punishment incompatible with Article $3 .^{76}$

After Soering, the ECtHR and European Commission on Human Rights subsequently rejected claims of cruel, inhuman and degrading punishment by detainees on death row in instances where there was a moratorium on executions or a legislative decision to defer executions in force, even though capital punishment technically remained a part of the law and current practice could be reversed. ${ }^{77}$ For example, the ECtHR in Iorgov v. Bulgaria ${ }^{78}$ was unsympathetic to the applicant's claim "that he suffered immensely at the thought of his possible execution and that it was inhuman to keep him in such uncertainty for many years." ${ }^{79}$ According to the ECtHR, there was a Parliamentary moratorium on executions in place and not a single violation of the moratorium had occurred, ${ }^{80}$ such that the applicant's "feelings of fear and anxiety must have diminished as time went on and as the moratorium continued in force." ${ }^{11}$ Similarly, the European Commission on Human Rights held in Çinar v. Turkey (Çinar) ${ }^{82}$ that the applicant's detention on death row was not particularly inhuman or degrading in violation of Article 3 because any threat of execution was illusory, given that Turkey had a longstanding moratorium on executions

\footnotetext{
75 Sadoff, supra note 66 , at 82-83.

76 Soering, App. No. 14038/88, 161 Eur. Ct. H.R. (ser. A) 92.

77 Sadoff, supra note 66, at 83.

78 Iorgov v. Bulgaria, App. No. $40653 / 98$ (2004).

79 Id. 975.

$80 \quad I d .9976,78$.

81 Id. 79.

82 Çinar v. Turkey, App. No. 17864/91 (1994).
} 
in place, such that everyone knew Turkey was no longer executing prisoners. ${ }^{83}$ The ECtHR's subsequent deviation from Çinar in Öcalan $v$ Turkey ${ }^{84}$, where the Grand Chamber found it "not possible to rule out the possibility that the risk that the [death] sentence would be implemented was a real one" notwithstanding Turkey's longstanding moratorium on executions, must be regarded as restricted to the "special circumstances" of that case, specifically the applicant's special status as "Turkey's most wanted person" who "had been convicted of the most serious crimes existing in the Turkish Criminal Code", and the "general political controversy in Turkey" "surrounding the question of whether he should be executed." 85

China's suspended death sentence does not meet this threshold requirement for a finding of cruel, inhuman and degrading punishment because there is no real risk of the convict being executed. Granted, the suspended death sentence "has the potential to be amended, at any time within the two-year period, to a sentence of immediate death if the criminal reoffends in prison." ${ }^{86} \mathrm{After}$ all, the unique feature of the suspended death sentence is the indeterminacy of the outcome at the end of the two-year reprieve, compared to other punishments like life imprisonment where the nature and implications of the punishment are made clear to the offender at the outset ${ }^{87}$ However, according to Chinese practice, the convict is virtually never executed at the end of the two-year reprieve. This was the case prior

$83 \quad I d$. at 8.

84 Öcalan v. Turkey, App. No. 46221/99, 37 Eur. H.R. Rep. 238 (2005).

85 Id. I 172.

86 Trevaskes, supra note 25, at 121.

87 Zhao Zuojun, supra note 5, at 75 n.15. 
to the enactment of the 1979 Criminal Law, ${ }^{88}$ under the 1979 Criminal Law, ${ }^{89}$ and under the current 1997 Criminal Law. ${ }^{90}$

88 According to several scholars, "most" suspended death sentences before the enactment of the 1979 Criminal Law were commuted to a life or fixed-term imprisonment. CoHen, supra note 56, at 537; Hungdah Chiu, Criminal Punishment in Mainland China: A Study of Some Yunnan Province Documents, 68 Journal of Criminal LaW and Criminology 374, 390 n.38 (1977) (noting how, according to PRC officials, only a few criminals sentenced to a suspended death penalty are actually executed at the end of the two-year period.); SHaochuan Leng \& HoNGdAH CHIU, supra note 45, at 157 n.23 (noting how the warden of the Shanghai Municipal Prison told a group of visiting American legal scholars in 1981 that no prisoners in the institution with suspended death sentences had ever been executed).

89 This may have been the intention of the National People's Congress when the 1979 Criminal Law was enacted. A National People's Congress official stated in 1979 that "[g]enerally speaking," those receiving the reprieve will not be executed. Amnesty InT'L, supra note 22, at 63. Lepp and Davis both claim that the "majority" of suspended death sentences were commuted. Alan W. Lepp, The Death Penalty in Late Imperial, Modern, and Post-Tiananmen China, 11 Michigan Journal of International Law 987, 1034 (1990); Stephen B. Davis, The Death Penalty and Legal Reform in the PRC, 1 Journal of Chinese LaW 303, 314 (1987). According to Scobell, executions were "rarely" carried out at the end of the two-year reprieve. Andrew Scobell, Strung Up or Shot Down: The Death Penalty in Hong Kong and China and Implications for Post-1997, 20 Case Western Reserve Journal of INTERNATIONAL LAW 147, 159 (1988).

90 One scholar claims that, in practice, "99\%" of suspended death sentences are commuted to life or fixed-term imprisonment. Michelle Miao, Examining China's Responses to the Global Campaign Against the Death Penalty, in Confronting Capital Punishment in Asia: Human Rights, Politics and Public Opinion 46, $49-50$ (Roger Hood \& Surya Deva eds. 2013). Another scholar even terms the "suspended death sentence" the "reprieved death sentence" because the "increasingly common pattern" is that the sentence is "seldom actually carried out once the two-year period expires." Lewis, supra note 45, at 307 n.13. However, Amnesty International reported in 2009 that, of the many sentenced to death in the Xinjiang Uighur Autonomous Region, some who had been given suspended death sentences were executed in 2008.” Amnesty Int'L, Amnesty International Report 2009: The State of THE World's Human Rights 109 (2009), http://www.amnesty.org.au/images/ uploads/about/ai_report_09.pdf. 


\section{b. Does the Two-Year Reprieve Amount to Cruel, Inhuman and Degrading Punishment?}

Even if we accept that there is still a real risk of the convict being executed at the end of the two-year reprieve, there still remains the question of whether the two-year reprieve constitutes cruel, inhuman and degrading punishment. Addressing this question would require an analysis of two contrasting approaches in the jurisprudence of domestic and international courts which are divided as to when the death row phenomenon is present ${ }^{91}$ (assuming these courts have accepted the doctrine in the first place ${ }^{92}$ ).

The first approach in the death row phenomenon jurisprudence holds that delay of execution per se is a sufficient supervening event which on its own constitutes cruel, inhuman and degrading punishment. This is the position adopted by courts in the Commonwealth jurisdictions like

91 Sadoff, supra note 66, at 79 ("Soering has spawned a body of international and domestic case law, most-but not all-of which recognizes the validity of the death row phenomenon. But even among those courts adopting it in principle, its application has been far from uniform."); Bojosi, supra note 67, at 305 ("Legal scholars, psychologists and judges appear to be unanimous about the existence of the death row phenomenon. However, the jurisprudence of national courts and international courts and/or tribunals is sharply divided about its precise contours").

92 The United States judiciary has refused to accept the death row phenomenon doctrine. The United States Supreme Court rejected petitions for a writ of certiorari in cases where prisoners claimed that the delay in their executions violated the Eighth Amendment to the U.S. Constitution prohibits "cruel and unusual punishments." U.S. Const. amend. VIII. The cases where the Supreme Court has denied such petitions include Foster v. Florida, 537 U.S. 990 (2002); Knight v. Florida, 528 U.S. 990 (1999); Elledge v. Florida, 525 U.S. 944 (1998); Lackey v. Texas, 514 U.S. 1045 (1995). 
South Africa, ${ }^{93}$ India ${ }^{94}$ and Zimbabwe,,${ }^{95}$ and most significantly, the Judicial Committee of the Privy Council (the highest court of appeal for many Caribbean States). The momentous case of Pratt and Morgan v Jamaica (Pratt) ${ }^{96}$ marked the first time the Privy Council accepted the death row phenomenon. In Pratt, the Privy Council held that delay in itself was sufficient to constitute cruel or inhuman punishment, noting that:

[T] here is an instinctive revulsion against the prospect of hanging a man after he has been held under sentence of death for many years. What gives rise to this instinctive revulsion? The answer can only

93 The Constitutional Court of South Africa determined in 1995 that "prolonged delay in the execution of a death sentence may in itself be cause for the invalidation of a sentence of death that was lawfully imposed." State v. Makwanyane 1995 (3) SA 391 (CC) at 3 para. 6 n.3 (S. Afr.).

94 The Indian Supreme Court found the issue of "prolonged delay“ relevant to the implementation of a death sentence, and has commuted such sentences to terms of life imprisonment in instances of lengthy "delays." Singh v. Punjab, (1983) 2 SCR 582 (India); Vatheeswaran v. Tamil Nadu, (1983) 2 SCR 348 (India); Mehta v. Union of India, (1989) 3 SCR 774, 777 (India).

95 In 1993, the Supreme Court of Zimbabwe found that the mental grief suffered by four prisoners was sufficient to justify commuting their death sentences to life imprisonment on constitutional grounds. Catholic Comm'n for Justice \& Peace in Zimbabwe v. Attorney Gen. (1993) 1 ZLR 242 (S), 4 SA 239 (ZSC) (Zim.). These prisoners who had been on death row for four to six years each, had contemplated suicide, and had suffered the constancy of their upcoming executions. Id. This Supreme Court ruling was based on section 15(1) of the Zimbabwean Declaration of Rights, which reads almost identically to article 3 of the ECHR. Id. Gubbay C.J. referred to the approach he adopted in this case as more "progressive" and “compassionate." Id. at 333.

96 Pratt \& Morgan v. Jamaica [1993] 4 All ER 769 (PC) (appeal taken from Jam.). The case arose when two death row prisoners claimed that, after 14 years, carrying out the death sentence would violate Jamaica Constitution, which provides, "[n]o person shall be subjected to torture or to inhuman or degrading punishment or other treatment." Constitution of Jamaica Aug. 6, 1962, art. 17(1). 
be our humanity: we regard it as an inhuman act to keep a man facing the agony of execution over a long extended period of time. ${ }^{97}$

Taking into account the fact that Jamaican appeals process should be completed within two years, and that appeals to international tribunals should be completed within 18 months, the Privy Council in Pratt held that "in any case in which execution is to take place more than five years after sentence there will be strong grounds for believing the delay [is a violation]."98 Subsequently, the five-year threshold established in Pratt was not consistently followed by the Privy Council in death row appeal cases, resulting in much confusion ${ }^{99}$ and scholarly criticism for its arbitrariness and rigidity. ${ }^{100}$ Applying the Privy Council's rule in Pratt to China's suspended death sentence, the two-year period falls far short of the five-year guideline (or even the three-and-a-half-year guideline, assuming the prisoner does not appeal to international tribunals as was the case in Henfield). Therefore, the suspended death sentence does not constitute cruel, inhuman and degrading punishment under this first approach.

The second, narrower approach in the death row phenomenon jurisprudence - which this article considers to be the preferable approach - holds that delay of execution per se does not, in itself, constitute cruel, inhuman

97 Pratt \& Morgan, [1993] 4 All ER at 783.

$98 \quad$ Id. at 788.

99 In Guerra v. Baptiste [1996] 1 AC 397, 414 (PC) (appeal taken from Trin. \& Tobago), the Privy Council found a four-year-and-ten-month delay unacceptable, stating that the five-year limit enunciated in Pratt \& Morgan "was not intended to provide a limit, or a yardstick." Months later, in a change of course, the Privy Council held that five years needed to be reached before a violation could occur, and if the delay was caused by a stay issued so that the prisoner could argue points of mercy, this would extend the five-year period. Reckley v. Minister of Pub. Safety \& Immigration (No. 2) [1996] 1 AC 527 (PC) (appeal taken from Bah.). Subsequently in Henfield v. AG of the Commonwealth of the Bahamas [1996] 3 WLR 1079, 1088 (PC) (appeal taken from Bah.), the Privy Council held that three and a half years was the appropriate time limit where the prisoner does not pursue appeals to international organisations (because the Privy Council in Pratt \& Morgan had earlier held that the estimated time for appeals to international tribunals was eighteen months) such that eighteen months was to be subtracted from the five-year guideline.

100 Hudson, supra note 65, at 852; Sadoff, supra note 66, at 99-100. 
and degrading punishment; rather, the conditions of detention on death row must be extremely harsh and dehumanising. This is the approach adopted by the United Nations Human Rights Committee (HRC). Made up of 18 independent experts, the HRC determines individual communications on alleged violations of the ICCPR in states that are parties to the Optional Protocol to the ICCPR, ${ }^{101}$ and according to the International Court of Justice, the HRC "has built up a considerable body of interpretative case law, in particular through its findings in response to the individual communications" and "great weight" should be ascribed to the HRC's interpretation of the ICCPR. ${ }^{102}$ Further, as Gandhi noted,

[T]he Human Rights Committee stands on an entirely different footing to domestic courts and, indeed, the European Court of Human Rights which is only a regional as opposed to a universal instance. Nevertheless, the Human Rights Committee does not operate in a legal vacuum. It will take note of the jurisprudence of other national and regional jurisdictions: sometimes this is by way of direct or indirect reference to the case law of these jurisdictions. More commonly, this may be by way of briefing papers of a comparative nature on specific legal issues requested by Committee members. ${ }^{103}$

The HRC stated its position on the death row phenomenon clearly in Pratt and Morgan v. Jamaica, ${ }^{104}$ that "[i]n principle prolonged judicial proceedings do not per se constitute cruel, inhuman, or degrading treatment even if they can be a source of mental strain for the convicted prisoners." 105 The reasons for the HRC's refusal to accept delay of execution in itself as cruel, inhuman and degrading punishment in violation of Article 7 of the

101 Optional Protocol to the International Covenant on Civil and Political Rights, Dec. 19, 1966, 999 U.N.T.S. 171.

102 Ahmadou Sadio Diallo (Guinea v. Dem. Rep. Congo), Merits, Judgment, 2010 I.C.J. Rep. 664, g 66 (Nov. 30).

103 P. R. Gandhi, The Human Rights Committee and the Death Row Phenomenon, 43 INDiAN JOURNAL OF INTERNATIONAL LAW 1, 60 (2003).

104 Pratt \& Morgan v. Jamaica, (Nos. 210/1986 and 225/19870, U.N. Doc. A/44/40 (1989).

105 Id. 13.6. 
ICCPR were set out clearly in Johnson v. Jamaica (Johnson). ${ }^{106}$ According to the HRC, it did not want to convey a message that would encourage States to expedite implementation of the death penalty within a specified time frame because "[l]ife on death row, harsh as it may be, is preferable to death." 107 This view is supported by academics ${ }^{108}$ and the UN Special Rapporteur on Torture and Other Cruel, Inhuman or Degrading Treatment or Punishment. ${ }^{109}$

Further, the HRC in Johnson held that allowing delay in execution per $s e$ to constitute a violation of the ICCPR would conflict with the ICCPR's object and purpose which was to promote the reduction of the death penalty. ${ }^{110}$; it would be inconsistent to hold that states which fail to execute a convict by delaying his execution have violated the ICCPR while also holding that states which execute convicts rapidly have adhered to the ICCPR. ${ }^{111}$ In subsequent cases the HRC has maintained the position that delay alone

106 Johnson v. Jamaica, (No. 588/1994), U.N. Doc. CCPR/C/56/D/588/1994 (1996).

107 Id. 8.4.

108 Hudson finds it "unusual" that a prisoner who would prefer to be executed than to cling on to hopes of having his or her life spared, and how some prisoners actually prove their innocence on appeal and a state may save an innocent life. Hudson, supra note 65 , at 847 . In a similar vein, Sadoff notes "the value inherent in the appeals process itself. The fact is that those petitioning for habeas corpus relief from death row, at least in the United States, have been remarkably successful in obtaining reversals on their death sentences." Sadoff, supra note 66, at 101. See McKenzie v. Day, 57 F.3d 1461, 1467 (9th Cir. 1995) ("By and large, the delay in carrying out death sentences has been of benefit to death row inmates, allowing them to extend their lives, obtain commutation or reversal of their sentences or, in rare cases, secure complete exoneration.").

109 U.N. Human Rights Council, Interim Report of the Special Rapporteur on Torture and Other Cruel, Inhuman or Degrading Treatment or Punishment, 47, U.N. Doc. A/67/279 (Aug. 9, 2012).

110 Johnson, (No. 588/1994), gg 8.2-.3, U.N. Doc. CCPR/C/56/D/588/1994.

111 Hudson, supra note 65, at 847 (also noting that "if the Committee finds a violation based on delay, the remedy is to commute the sentence to life imprisonment rather than impose a speedy execution. Therefore, finding a violation spares a prisoner's life, consistent with the Convention."). 
is insufficient to constitute cruel, inhuman and degrading punishment, ${ }^{112}$ and although it has shown some willingness to reconsider its position, it has not gone so far as to change it entirely. ${ }^{113}$

With delay per se being insufficient for a finding of cruel, inhuman and degrading punishment "in the absence of other compelling circumstances," 114 the HRC requires the presence of extremely harsh and dehumanising conditions of detention. Each case is to be examined on a fact-specific basis. ${ }^{115}$ While the HRC's jurisprudence is not altogether clear on exactly what would satisfy this requirement, ${ }^{116}$ it appears that the HRC has set a very high threshold in cases where it has accepted the death row phenomenon. ${ }^{117}$ In Francis $v$ Jamaica, ${ }^{118}$ the fact that the convict was regularly beaten and ridiculed by prison officers and subjected to roundthe-block surveillance in a special "death cell" adjacent to the gallows was a reason for the HRC's finding of an Article 7 violation. ${ }^{119}$ And in Edwards v. Jamaica, the "deplorable conditions of detention" where the convict had been detained for ten years "alone in a cell measuring six feet by 14 feet, let out only for three and half hours a day, [and] was provided with no recreational facilities and received no books" led the HRC to declare such detention conditions as constituting "not only a violation of article

112 See Spence v. Jamaica, (No. 599/1994), U.N. Doc. CCPR/C/57/D/599/1994 (1996); Sterling v. Jamaica, (No. 598/1994), U.N. Doc. CCPR/C/57/D/598/1994 (1996).

113 The HRC has also indicated that it "would be prepared to consider that the prolonged detention of the author on death row constitutes a violation of article 7. Persaud \& Rampersaud v. Guyana, (No. 812/1998), U.N. Doc. CCPR/ C/86/D/812/1998 (2006). However, having also found a violation of article 6, paragraph 1, it does not consider it necessary in the present case to review and reconsider its jurisprudence that prolonged detention on death row, in itself and in the absence of other compelling circumstances, does not constitute a violation of article 7." Id. 9.3 .

114 Id.

115 Williams v. Jamaica, (No. 609/1995), 9.4, U.N. Doc. CCPR/C/61/D/609/1995 (1997) (“[E]ach case must be examined on its own merits.").

116 Bojosi, supra note 67, at 320.

117 Sadoff, supra note 66, at 92; Hudson, supra note 65, at 846.

118 Francis v. Jamaica, (No. 606/1994), U.N. Doc. CCPR/C/54/D/606/1994 (1995).

119 Id. 9.2. 
10 , paragraph 1 , but, because of the length of time in which the author was kept in these conditions ... also a violation of article 7." 120 The HRC may deem evidence of the convict's actual mental deterioration to be a "compelling circumstance" justifying a finding of an Article 7 violation ${ }^{121}$ but such evidence is not strictly required; the extremely harsh and dehumanising conditions of detention may suffice. ${ }^{122}$

Such a high threshold set by the HRC regarding conditions of detention would make it extremely difficult to prove a violation of Article 7 of the ICCPR, ${ }^{123}$ and, correspondingly, to prove that China's suspended death sentence constitutes cruel, inhuman and degrading punishment. While the conditions on death row in China are extremely harsh, with the "use of shackles for 24 hours" probably "amounting to cruel, inhuman or degrading treatment" as the United Nations Committee Against Torture has contended, ${ }^{124}$ convicts who have received the suspended death sentence are not placed on death row together with persons sentenced to immediate execution without any reprieve: they are normally held in prison with convicts sentenced to life and fixed-term imprisonment of over 10 years, ${ }^{125}$ and are usually required to participate in "labour reform." ${ }^{126}$ Such labour

120 Edwards v. Jamaica, (No. 529/1993), 8.3, U.N. Doc. CCPR/C/60/D/529/1993 (1993). Article 10(1) of the ICCPR states, "[a]ll persons deprived of their liberty shall be treated with humanity and with respect for the inherent dignity of the human person." ICCPR, supra note 9, art. 10(1).

121 Francis, (No. 606/1994), 9.2, U.N. Doc. CCPR/C/54/D/606/1994; Williams, (No. 609/1995), 6.5, U.N. Doc. CCPR/C/61/D/609/1995.

122 Sadoff, supra note 66, at 92.

123 Hudson, supra note 65, at 846.

124 Commission on Human Rights, Report of the Special Rapporteur on Torture and Other Cruel, Inhuman or Degrading Treatment or Punishment, Manfred Nowak: Mission to China, 34, U.N. Doc. E/CN.4/2006/6/Add.6 (Mar. 10, 2006).

125 MacBean, supra note 8, at 23.

126 The sample decision for the approval of a sihuan which reads “核准 $\times \times \times \times$ 中级 人民法院 $(X \times \times \times) \times$ 刑初字第 $\times \times$ 号以 $\times \times$ 罪判处被告人 $\times \times \times$ 死刑, 缓期二 年执行, 劳动改造, 以观后效, 剥夺政治权利终身的刑事判决。" (which means: suspension of sentence for two years, labour reform), Higher People's Court, Crim. Procedural L., http://course.sdu.edu.cn/G2S/Template/View.aspx?cours eType $=1 \&$ courseId=220\&topMenuId=123682\&menuType=1\&action=view\&type $=\&$ name $=\&$ linkpageID $=124704$ (last visited May 4, 2016). Further, Article 213 of 
reform that convicts who have received the suspended death sentence are subjected to has been defended by the Chinese government to be "a good way to make criminals turn over a new leaf... educat[e] law offenders [and] help them ... transform themselves ideologically." ${ }^{27}$ While this has been criticised by commentators for entailing the "agony of self-reform" 128 and for the "undeniable danger" of its "strong brainwashing consequences,"129 the suspended death sentence is unlikely to satisfy the extremely high threshold set by the HRC in determining the presence of extremely harsh

the Criminal Procedure Law provides that criminals issued the suspended death sentence - together with those sentenced to life or fixed-term imprisonment - are to be transferred to the prison by the public security (police) authorities. Criminal Procedure Law of the People's Republic of China (promulgated by the Standing Comm. Nat'l People of Cong., July 1, 1979, amended Mar. 17, 1996, effective Jan. 1, 1997), art. 213. Article 46 of the 1997 Criminal Law, provides that persons sentenced to life or fixed-term imprisonment who have the ability to labour should participate in labour and accept education and reform. 1997 Criminal Law, supra note 2, art. 46 . While Article 46 does not expressly state that persons issued the suspended death sentence would have to do the same, given that they are imprisoned together with those sentences to life and fixed-term imprisonment, and given that there remains the possibility of a commutation of sentence to life or even fixed-term imprisonment, by deduction, persons issued the suspended death sentence should also be deemed to "participate in labour" and "accept education and reform." Id.

127 Amnesty Int'L, supra note 22, at 64.

128 An American writer, Edgar Snow, interviewed a political offender in 1962 who was issued the suspended death sentence, and observed that this convict "seemed thoroughly humbled and remorseful," with "deep tension was written on his face. CoHen, supra note 56. One needed little imagination to share some of the awareness that must have filled his days that one bad mistake might be his last. Id. To know with reasonable certainty that salvation depended entirely on his own repentance and reform must in some ways have placed far heavier burdens on him than would be on a condemned man in an American prison. Id. Realizing that nothing he can do by way of inner awakening can alter matters, the latter need not undergo the agony of self-reform but can hold society or his lawyers at least partly responsible for his fate." Id. at 539.

129 Shigemitsu Dando, The Criminal Law Of Japan: The General Part 291 n.22 (B. J. George trans., 1997). 
and dehumanising conditions of detention necessary for a finding of cruel, inhuman and degrading punishment.

\section{CONCLUSION}

The issue of whether China's suspended death sentence constitutes cruel, inhuman and degrading punishment is an important one with far-ranging implications. This issue arose before the Federal Court of Canada in 2007. In Lai v. Canada (Minister of Citizenship and Immigration), ${ }^{130}$ two Chinese nationals who allegedly committed offences of bribery and smuggling claimed refugee status in Canada. After the pre-removal risk-assessment (PRRA) officer rejected their application, they sought judicial review of this decision, and one of their arguments was that China's suspended death sentence (which the applicants could face if deported to China) constitutes cruel and unusual punishment, even if the applicants would not be executed. ${ }^{131}$ This issue may arise once again in the future in such asylum cases involving the return of Chinese nationals to China to face prosecution and risk being sentenced to death with a two-year reprieve. This may be of especial relevance in states parties to the ICCPR, given that states parties "must not expose individuals to the danger of . . cruel, inhuman or degrading treatment or penalty upon return to another country by way of their extradition, expulsion or refoulement."132

Moreover, other states have considered introducing the suspended death sentence into their respective criminal justice systems. When revising its criminal law in the 1980s, Japan considered adopting China's death sentence

130 Lai Cheong Sing v. Minister of Citizenship \& Immigration, [2007] F.C. 361 (Can.).

131 Id. 83. The Court did not address the question of whether China's suspended death sentence per se constitutes cruel and unusual punishment, but rejected the applicants' argument on the basis that the diplomatic assurances made by the Chinese government to the Canadian government in regards to the applicants precluded the imposition of a suspended death sentence and, given that the likelihood of any death sentence was foreclosed altogether, there was no possibility of the applicants' experiencing psychological trauma associated with awaiting an execution which may or may not arrive. Id. at 100.

132 Human Rights Committee, General Comment No. 20: Article 7, Prohibition of Torture, or Other Cruel, Inhuman or Degrading Treatment or Punishment, 9, U.N. Doc. HRI/Gen/Rev.1, 30 (1994). 
with a two-year suspension. ${ }^{133}$ However, this proposal never made it to the Diet. ${ }^{134}$ Further, in 2006, Taiwan's Ministry of Justice seriously considered the suspended death sentence as a reform measure. ${ }^{135}$ However, this suggestion encountered some resistance, ${ }^{136}$ and eventually failed to materialise. ${ }^{137} \mathrm{~A}$

133 Zhao Zuojun, supra note 5, at 55.

134 Johnson \& Zimring, supra note 15 , at 34.

135 Minister of Justice, Morley Shih, was quoted as saying that the Ministry was studying the possibility of following China's example to issue the death sentence with a two-year suspension to give criminals the chance to repent. MOJ Turns to PRC for Inspiration on Cutting Executions, Taipei Times (Jan. 1, 2006), http:// www.taipeitimes.com/News/taiwan/archives/2006/01/01/2003286887.

136 The Taiwan Alliance to End the Death Penalty opposed the ministry's plan, pointing out how it contradicted President Chen Shui-bian's 2000 inauguration promise to abolish the death penalty. Id. According to a member of the Alliance, " $[\mathrm{u}]$ nder the measure of 'death penalty with two years,' only those who have behaved well are eligible for having their death penalty converted to a life sentence. We demand a moratorium on all executions and the eventual abolition of the death penalty." Id. And according to Associate Professor Wu Chih-kuang, "[a]dopting this system, however, would be taking a step backward, instead of moving along the correct path toward eventually abolishing the death penalty. China delays the execution of death sentences, but the death penalty remains in place. In other words, courts still have absolute power to deliver final judgment. This would not be the case if capital punishment was replaced by a full-fledged moratorium. Delaying the execution of a death sentence does not cut down on abuse of capital punishment, nor will it reduce criticism from the outside world. The ministry's plan to introduce China's system for commuting death sentences to life imprisonment without actually abolishing capital punishment will not stop courts from issuing the death penalty, nor does it move the nation closer to abolishing the death penalty. Even if the ministry is determined to delay the execution of every death sentence, we feel that retaining the possibility of executing a death sentence goes against the global trend toward abolishing capital punishment." Wu Chih-kuang, Justice Ministry on the Wrong Path, TAipei Times (Jan. 19, 2006), http://www. taipeitimes.com/News/editorials/archives/2006/01/19/2003289715.

137 However, as recent as in 2013, there was a call for the revival of this proposal by the Chairman of the non-governmental organisation, the Chinese Association for Human Rights. Su Yiu-chen, Respecting Life While Bringing Justice, Taipei Times (Aug. 13, 2013), http://www.taipeitimes.com/News/editorials/ archives/2013/08/13/2003569564. 
couple of death penalty experts have also suggested that the suspended death sentence is a useful model for other States to emulate. ${ }^{138}$ Clarifying that the suspended death sentence does not amount to cruel, inhuman and degrading punishment, as this article has aimed to do, may assist other States (especially states parties to the ICCPR) to better decide whether to introduce the suspended death sentence into their respective criminal justice systems, given that the prohibition against cruel, inhuman and degrading punishment is a non-derogable human right under the ICCPR ${ }^{139}$ and thus of great importance.

138 Johnson \& Zimring, supra note 15, at 219 n.34 (stating that " $\mathrm{t}$ ] here is also at least one way Taiwan might emulate China: by enacting a reform that would allow a death sentence to be suspended for two years while the behavior and attitude of the condemned is assessed."); Zimring \& Johnson, supra note 37, at 195 (stating that in regard to the suspended death sentence, China is "miles ahead of other nations.").

139 Article 4(1) of the ICCPR states, "[i]n time of public emergency which threatens the life of the nation and the existence of which is officially proclaimed, the States Parties to the present Covenant may take measures derogating from their obligations under the present Covenant to the extent strictly required by the exigencies of the situation, provided that such measures are not inconsistent with their other obligations under international law and do not involve discrimination solely on the ground of race, colour, sex, language, religion or social origin" ICCPR, supra note 9, at art. 4(1). Article 4(2) states, "[n]o derogation from articles 6, 7, 8 (paragraphs 1 and 2), 11, 15, 16 and 18 may be made under this provision." Id. art. $4(2)$. 